\title{
Regulatory roles of G-protein coupled receptors in adipose tissue metabolism and their therapeutic potential
}

\author{
Hyeonyeong $\operatorname{Im}^{1} \cdot$ Ji-Hyun Park ${ }^{1} \cdot$ Seowoo Im ${ }^{1}$. \\ Juhyeong Han ${ }^{1} \cdot$ Kyungmin Kim $^{1} \cdot$ Yun-Hee Lee ${ }^{1}$
}

Received: 11 October 2020 / Accepted: 18 January 2021 / Published online: 7 February 2021

(C) The Author(s) 2021

\begin{abstract}
The high incidence of obesity has increased the need to discover new therapeutic targets to combat obesity and obesity-related metabolic diseases. Obesity is defined as an abnormal accumulation of adipose tissue, which is one of the major metabolic organs that regulate energy homeostasis. However, there are currently no approved anti-obesity therapeutics that directly target adipose tissue metabolism. With recent advances in the understanding of adipose tissue biology, molecular mechanisms involved in brown adipose tissue expansion and metabolic activation have been investigated as potential therapeutic targets to increase energy expenditure. This review focuses on G-protein coupled receptors (GPCRs) as they are the most successful class of druggable targets in human diseases and have an important role in regulating adipose tissue metabolism. We summarize recent findings on the major GPCR classes that regulate thermogenesis and mitochondrial metabolism in adipose tissue. Improved understanding of GPCR signaling pathways that regulate these processes could facilitate the development of novel pharmacological approaches to treat obesity and related metabolic disorders.
\end{abstract}

Keywords GPCR - Obesity - Adipose tissue . Adrenoceptor - Adenosine receptor · Frizzled receptor . Lysophospholipid receptor

Hyeonyeong Im and Ji-Hyun Park have contributed equally to this work.

Yun-Hee Lee

yunhee.lee@snu.ac.kr

1 College of Pharmacy and Research Institute of Pharmaceutical Sciences, Seoul National University; BioMAX Institute, Seoul National University, 29-Room \# 311, 1 Gwanak-ro, Gwanak-gu, Seoul 08826, Republic of Korea

\section{Introduction}

G protein-coupled receptors (GPCRs), one of the largest protein receptor families, are seven-transmembrane-domain protein receptors that mediate various downstream signals by interacting with $\mathrm{G}$ protein complexes ( $\alpha$ and $\beta \gamma$ ) (Weis and Kobilka 2018).

Ligand binding to GPCRs induces conformational changes in the receptors, which activates exchange of guanosine triphosphate for guanosine diphosphate on the $\mathrm{G} \alpha$ subunits (Marinissen and Silvio Gutkind 2001), resulting in the dissociation of the $\mathrm{G} \beta \gamma$ dimer from $\mathrm{G} \alpha$. Based on their sequence homologies and functional similarities, $\mathrm{G} \alpha$ proteins are categorized into four major groups: $\mathrm{G} \alpha_{\mathrm{s}}, \mathrm{G \alpha}_{\mathrm{i} / \mathrm{o}}$, $\mathrm{G} \alpha_{\mathrm{q}}$, and $\mathrm{G} \alpha_{12 / 13}$ (Syrovatkina et al. 2016), and activate distinct downstream effectors (Syrovatkina et al. 2016).

GPCRs are the most successful class of druggable targets in human diseases (Quiñones et al. 2019), estimated to be targeted by approximately $34 \%$ of the FDA-approved drugs (Hauser et al. 2017). The disease indications for GPCR regulators, including cardiovascular, immunological, and metabolic disorders, have been greatly expanded (Hauser et al. 2017). For example, glucagon-like peptide-1 receptor agonists for the treatment of obesity and type 2 diabetes mellitus are a well-known class of recently approved drugs that act on GPCRs (Husted et al. 2017; Sloop et al. 2018).

Adipose tissue, which can be white or brown, is a major metabolic organ that regulates energy homeostasis (Kershaw and Flier 2004; Cannon and Nedergaard 2004). Adipocytes are specialized cell types responsible for lipid metabolism, including catabolic lipolysis, anabolic de novo lipogenesis, and triglyceride (TG) accumulation (Rosen and Spiegelman 2006). In general, white adipose tissue (WAT) is an endocrine organ that stores surplus nutrients as TG in lipid droplets, occupying $95 \%$ of the cell mass (Trayhurn and 
Beattie 2001; Lee, Wu, and Fried 2013). During negative energy balance, WAT hydrolyzes TG and mobilizes free fatty acids (FFA) into the circulation to supply systemic energy demands (Rosen and Spiegelman 2014).

Continuous positive energy balance results in hypertrophic expansion of WAT and TG accumulation exceeding the storage capacity of adipose tissue, causing ectopic fat accumulation in non-adipose organs (Sun et al. 2013; Rosen and Spiegelman 2006). Moreover, this hypertrophic response is often associated with inflammation, insulin resistance, and metabolic syndromes (Verboven et al. 2018; Grundy 2004; Furukawa et al. 2017). Although lipolysis can be targeted to reduce fat mass, excess WAT lipolysis is associated with increased circulating FFAs and lipotoxicity, which might contribute to nonalcoholic fatty liver disease and insulin resistance (Samuel and Shulman 2012). Therefore, pharmacological targeting of WAT lipolysis might be challenging due to adverse effects.

In contrast, brown adipose tissue (BAT) is a specialized thermoregulatory organ that dissipates FFAs into heat (Cannon and Nedergaard 2004). BAT contains high levels of mitochondria and is molecularly characterized by uncoupling protein 1 (UCP1) expression (Cannon and Nedergaard 2004). It has been well accepted that activation of BAT metabolism results in enhanced energy expenditure and improved insulin sensitivity and metabolic profiles (Peng et al. 2015; Kajimura, Spiegelman, and Seale 2015). Importantly, white adipocytes can be converted into brown like adipocytes under physiological and pharmacological thermogenic stimuli, a phenomenon defined as WAT browning (Lee, Mottillo, and Granneman 2014; Kajimura, Spiegelman, and Seale 2015). Therefore, molecules that regulate the thermogenic pathways in BAT and WAT have been intensively studied as a promising target to treat or prevent obesity and obesity-related metabolic syndromes (Kim and Plutzky 2016).

In this review, we summarized recent findings on five GPCR subfamilies that regulate thermogenesis and mitochondrial metabolism in BAT and WAT: beta adrenoceptors, alpha adrenoceptors, adenosine receptors, frizzled receptors, and lysophospholipid receptors. Our goal is to provide the current understanding of GPCR-related molecular mechanisms that regulate adipose tissue metabolism and potentially aid the development of novel targets for obesity and obesity-related metabolic diseases.

\section{Relative abundance of gene expression levels of GPCRs in adipose tissue}

We analyzed and compared the relative expression levels of GPCRs in mice and humans using in-house and public RNAseq data (GSE148275 and GSE135134). The list of genes classified into GPCRs was obtained from the
IUPHAR/BPS guide to pharmacology (http://www.guide topharmacology.org/GRAC/FamilyDisplayForward?famil yId=694).

GPCR subfamilies expressed higher than $1 \%$ of the total GPCR expression in mouse WAT are listed and compared to the distribution of GPCR subfamilies in mouse BAT in Fig. 1. Similarly, GPCR subfamilies expressed higher than $0.5 \%$ of the total GPCR expression in human subcutaneous WAT from individuals with normal adiposity (body mass index $(\mathrm{BMI})<25)$ are listed and compared to the distribution of GPCR subfamilies in WAT of obese individuals $(\mathrm{BMI} \geq 30)$.

Based on previous studies related to the regulation of thermogenesis and mitochondrial metabolism in adipose tissue, we reviewed five GPCR subfamilies, namely beta adrenoceptors, alpha adrenoceptors, adenosine receptors, frizzled receptors, and lysophospholipid receptors. G protein subtypes coupling to the specific GPCRs are listed in Table 1, and the effects of the GPCR agonists/antagonists on adipose tissue metabolism are summarized in Table 2.

\section{Beta adrenoceptors}

There are three subtypes of beta adrenoceptors ( $\beta$-ARs), adrenoceptor $\beta 1$ - ( $\beta 1-\mathrm{AR}), \beta 2-(\beta 2-\mathrm{AR})$, and $\beta 3$ - ( $\beta 3$-AR), expressed in both BAT and WAT (Collins 2012; Hayward, Mueller, and Hasser 2004). $\beta$-ARs are coupled to $G_{s}$ proteins and activate adenylyl cyclase that increases intracellular cyclic adenosine monophosphate (cAMP) levels and phosphorylation of protein kinase A (PKA) (Evans et al. 2019) as shown in Fig. 2. Catecholamine-mediated sympathetic activation through $\beta$-ARs is a major canonical pathway that triggers lipolysis in brown and white adipocytes (Green et al. 1992; Enocksson et al. 1995; Collins 2012).

Among the three beta adrenoceptors, $\beta 3$-AR is the most recently discovered subtype and is mainly expressed in adipose tissue (Collins 2012). In adipocytes, activated $\beta 3$-AR induces cAMP production, and cAMP-dependent PKA phosphorylates downstream substrates, such as hormonesensitive lipase for lipolysis (Shin et al. 2016; Finlin et al. 2018). Another example of PKA phosphorylation substrates is the electron transport system complex, which modulates mitochondria oxidative phosphorylation (Amer and HebertChatelain 2018). Isoproterenol also induces mitochondrial activity by stimulating $\beta$-ARs in adipocytes (Cho et al. 2009). Selective $\beta 3$-AR agonists have been developed for adipocyte-specific lipolysis activators and anti-obesity therapeutics (Himms-Hagen et al. 1994; Arch 2002). However, clinical trials were unsuccessful due to relatively poor activity in humans compared to preclinical studies (Christopher et al. 2001). It was believed that human white adipocytes lack $\beta 3$-AR, hindering the anti-obesity effects of $\beta 3$-AR agonists (Ramseyer and Granneman 2016). However, in more 


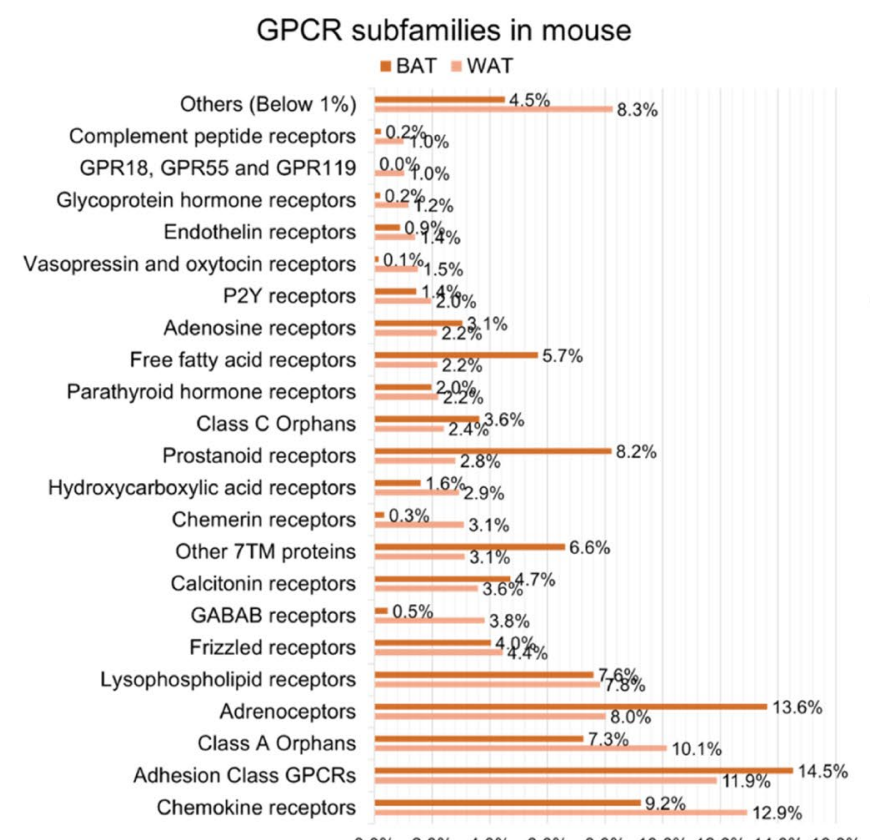

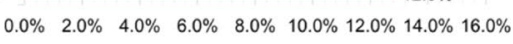

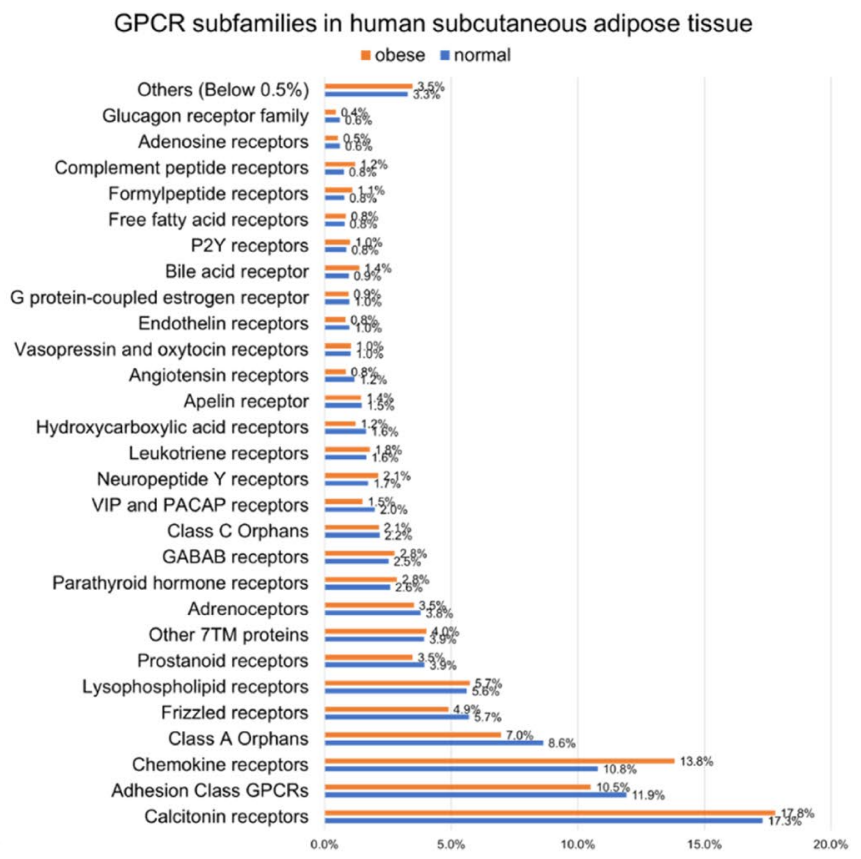

GPCR subfamilies in human subcutaneous adipose tissue

Others (Below 0.5\%) $3.3 \%$

ormylpeptide receptors $=0.3$ y acid receptors $=8.8 \%$

protein-coupled estrogen receptor $=9.8 \%$

Endothelin receptors $=0,80^{\circ}$ Angiotensin receptors $=0.8 \%$ Apelin receptor $=1$. Adrenoceptors 3.5

Frizzled receptors $=4.9 \%$

Chesion Class GPCRs $10.5 \%$

Calcitonin receptors

$0.0 \% \quad 5.0 \%$

Fig. 1 Relative expression levels of GPCR subfamilies expressed in mouse and human adipose tissue (GSE148275 and GSE135134). The relative expression levels of GPCRs in mouse and human adipose tissue are presented based on public transcriptome data (GSE148275 and GSE135134). Wild type mice analyzed in GSE138275 were treated with tamoxifen, and analysis was performed after a wash-out period ( 2 weeks). Using the GEO dataset GSE135134, we separated the group into two, and obese includes individuals with BMI $>=30 \mathrm{~kg} / \mathrm{m}^{2}$, normal with BMI $<25 \mathrm{~kg} / \mathrm{m}^{2}$. A list of mus musculus and homo sapiens GPCR genes was referred to IUPHAR/BPS guide to pharmacology (http:// www.guidetopharmacology.org/GRAC/FamilyDisplayForward?familyId=694). We grouped the subfamilies below 1\% (or 0.5\%) of total GPCRs in the title of Others (Below 1\% (or 0.5\%))

recent studies, it has been reported that human visceral and subcutaneous adipose tissue expresses $\beta 3$-AR (Ramseyer and Granneman 2016). Along with the recent re-discovery of the metabolically active BAT in adult humans (Cypess et al. 2009; Virtanen et al. 2009), the anti-obesity effects of $\beta 3$-AR agonists have been revisited in clinical trials. For instance, clinical trials demonstrated that a high dose $(200 \mathrm{mg} /$ day $)$ of mirabegron improves BAT thermogenesis and WAT lipolysis, resulting in weight loss (Cypess et al. 2015). Mirabegron is a first-generation selective $\beta 3$-AR agonist approved for overactive bladder syndrome with a daily dose of $50 \mathrm{mg}$; thus, the effects of high mirabegron doses on human adipose tissue might be mediated through $\beta 1$-AR and not by selective activation of $\beta 3$-AR, as evidenced by the off-target effects, such as tachycardia, reported in these clinical trials (Malik et al. 2012). Several recent clinical studies with a lower dose $(50 \mathrm{mg} /$ day $)$ demonstrated that in obese people, mirabegron treatment (10-12 weeks) improved insulin resistance, reduced hemoglobin A1c levels, and increased the protein expression of UCP1 in subcutaneous WAT via cAMP-dependent PKA signaling (Finlin et al. 2018), suggesting the therapeutic potential of the $\beta 3$-AR agonist.

Although $\beta 1$-AR and $\beta 3$-AR are both activated by the same endogenous ligand, norepinephrine, mature brown adipocytes in rodents mainly express $\beta 3$-AR (approximately 50-fold higher than $\beta 1$-AR) (Collins et al. 1994) while species differences between humans and rodents should be accounted for (Granneman, Lahners, and Chaudhry 1991). While expression levels of $\beta 1$-AR decline during adipogenesis of mouse brown preadipocytes (Bronnikov et al. 1999), $\beta 1$-AR activation increases cAMP levels and facilitates cell proliferation of mouse brown preadipocytes in vitro (Bronnikov, Houstěk, and Nedergaard 1992). Consistently, $\beta 1$-AR is required for cold exposure-induced progenitor proliferation in mouse BAT (Lee et al. 2015). Although the predominant subtype is $\beta 3-\mathrm{AR}, \beta 1$-AR mediates cold-induced thermogenesis of BAT in mice (Ueta et al. 2012) and has compensatory effects in BAT of $\beta 3$-AR-deficient mice (Chernogubova et al. 2005a). Similarly, in vitro $\beta 1$-AR knockdown in immortalized human brown adipocytes reduced UCP1 induction following isoproterenol treatment (Evans et al. 2019; RiisVestergaard et al. 2020). Treatment with talinolol, a $\beta 1-A R$ selective antagonist, reduces cold exposure-induced browning in mice (Jiang, Berry, and Graff 2017).

Although $\beta 2$-AR can be found in BAT (Levin and Sullivan 1986; Chernogubova et al. 2005b; Rothwell, Stock, and Sudera 1985), it is thought to be expressed mostly in the blood vessels of rodent BAT (Bengtsson, Cannon, and Nedergaard 2000; Chernogubova et al. 2005b). Indeed, $\beta 2$-AR stimulation increases blood flow and metabolic activity of 
Table 1 GPCR with its coupling G-proteins

\begin{tabular}{|c|c|c|c|}
\hline Receptors & Subtypes & Coupling G-protein & References \\
\hline Beta adrenoceptors & $\begin{array}{l}\beta 1-\mathrm{AR} \\
\beta 2-\mathrm{AR} \\
\beta 3-\mathrm{AR}\end{array}$ & Gos & Gurdal, Friedman, and Johnson (1995) \\
\hline Alpha adrenoceptors & $\begin{array}{l}\alpha 1-\mathrm{AR} \\
\alpha 2-\mathrm{AR}\end{array}$ & $\begin{array}{l}\text { G } \alpha 0 \\
\text { G } \alpha i\end{array}$ & Evans et al. (2019) \\
\hline Adenosine receptors & $\begin{array}{l}A_{1} R \\
A_{2 A} \\
A_{2 B} \\
A_{3} R\end{array}$ & 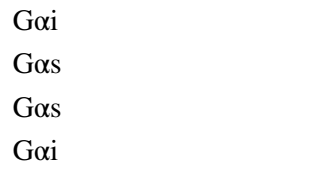 & Tozzi and Novak (2017b) \\
\hline Frizzled receptors & $\begin{array}{l}\text { FZD1 } \\
\text { FZD2 } \\
\text { FZD3 } \\
\text { FZD4 } \\
\text { FZD5 } \\
\text { FZD6 } \\
\text { FZD7 } \\
\text { FZD8 } \\
\text { FZD9 } \\
\text { FZD10 }\end{array}$ & 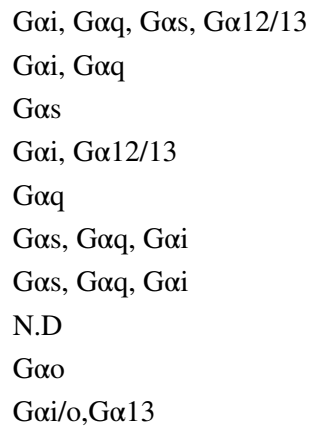 & $\begin{array}{l}\text { Nichols et al. (2013), Park et al. } \\
\text { (2015), Schulte and Wright (2018) }\end{array}$ \\
\hline Lysophospholipid receptors & $\begin{array}{l}\text { LPA1 } \\
\text { LPA2 } \\
\text { LPA3 }\end{array}$ & 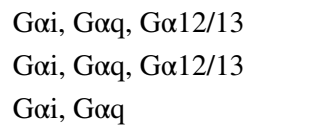 & Rosen et al. (2009) \\
\hline & $\begin{array}{l}\text { LPA4 } \\
\text { LPA5 } \\
\text { LPA6 }\end{array}$ & $\begin{array}{l}\mathrm{G} \alpha 12 / 13 \\
\mathrm{G} \alpha \mathrm{q}, \mathrm{G} \alpha 12 / 13 \\
\mathrm{G} \alpha 12 / 13\end{array}$ & $\begin{array}{l}\text { Yanagida et al. (2018) } \\
\text { Yung, Stoddard, and Chun (2014) }\end{array}$ \\
\hline & $\begin{array}{l}\text { S1PR1 } \\
\text { S1PR2 } \\
\text { S1PR3 } \\
\text { S1PR4 } \\
\text { S1PR5 }\end{array}$ & 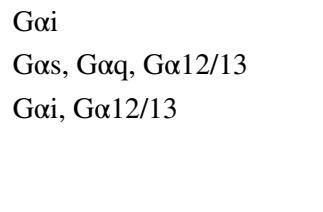 & Rosen et al. (2009) \\
\hline
\end{tabular}

BAT, without direct effects on oxygen consumption rates of isolated adipocytes (Ernande et al. 2016).

\section{Alpha adrenoceptors}

There are two types of alpha adrenoceptors, $\alpha 1$ and $\alpha 2$, each with three subtypes, namely, $\alpha 1 \mathrm{~A}, \alpha 1 \mathrm{~B}, \alpha 1 \mathrm{D}$ and $\alpha 2 \mathrm{~A}, \alpha 2 \mathrm{~B}$, $\alpha 2 \mathrm{C}$ (Evans et al. 2019). As described in Fig. 1, $\alpha 1$ adrenoceptors $(\alpha 1-\mathrm{AR})$ act on $\mathrm{G}_{\mathrm{q} / 11}$ proteins to activate phospholipase $\mathrm{C}$, while $\alpha 2$-ARs modulate Gi/o regulatory proteins to inhibit adenylyl cyclase (Evans et al. 2019). In a study on synovial adipose tissue-derived mesenchymal stem cells (ASCs), $\alpha 2$-ARs were found to be highly expressed in monolayer ASCs, compared to $\alpha 1$-AR (El Bagdadi et al. 2019).

Pharmacological activation of $\alpha 1-\mathrm{AR}$ in differentiated 3T3-L1 adipocytes by midodrine induces mitochondrial oxidative phosphorylation and ATP production through a PPAR $\delta$-AMPK-PCG- $1 \alpha$ pathway (Lee et al. 2020). Midodrine upregulates PPAR $\delta$, p-AMPK, and PGC- $1 \alpha$ protein levels, and reduces lipid content in differentiated 3T3-L1 adipocytes (Lee et al. 2020). These consequences were reversed by GSK0660, a PPAR $\delta$ antagonist (Lee et al. 2020).

In adipocytes, $\alpha 2$-AR activation inhibits lipolysis since it is negatively coupled to adenylyl cyclase (Lafontan and Berlan 1981). A study using transgenic knockout mice suggested a possible association between $\alpha 2$-AR and adipocyte hyperplasia since mice expressing $\alpha 2$-ARs in fat, in the absence of $\beta 3$-ARs ( $\beta 3$-AR -/- background), develop high-

fat diet-induced obesity (Valet et al. 2000). Although BAT is not significantly affected by transgenic expression (Valet et al. 2000), clonidine, an $\alpha 2$-AR agonist, reduces BAT thermogenesis (Antipov et al. 2020).

\section{Adenosine receptors}

Adenosine exerts a variety of effects in adipose tissue via multiple receptor subtypes, including $\mathrm{A}_{1}, \mathrm{~A}_{2 \mathrm{~A}}, \mathrm{~A}_{2 \mathrm{~B}}$, and $\mathrm{A}_{3}$ 
Table 2 GPCR agonists/antagonists that regulate adipose tissue metabolism

\begin{tabular}{|c|c|c|c|c|}
\hline Subfamilies & & Pharmacological agents & Effect & References \\
\hline \multirow[t]{7}{*}{$\beta$ Adrenoceptors } & \multirow[t]{2}{*}{ Non-selective } & \multirow[t]{2}{*}{ Isoproterenol (agonist) } & $\begin{array}{l}\text { Increased mitochondrial activ- } \\
\text { ity in 3T3-L1 adipocytes }\end{array}$ & Cho et al. (2009) \\
\hline & & & $\begin{array}{l}\text { UCP1 induction in human adi- } \\
\text { pocytes }\end{array}$ & $\begin{array}{l}\text { Evans et al. (2019), Riis-Vester- } \\
\text { gaard, Richelsen et al. (2020) }\end{array}$ \\
\hline & \multirow[t]{2}{*}{$\beta 1$} & Dobutamine (agonist) & $\begin{array}{l}\text { Increased lipolysis and ther- } \\
\text { mogenesis in human, UCP1 } \\
\text { induction in human brown } \\
\text { adipocytes }\end{array}$ & $\begin{array}{l}\text { Green et al. (1992), Riis-Vester- } \\
\text { gaard, Richelsen et al. (2020) }\end{array}$ \\
\hline & & Talinolol (antagonist) & $\begin{array}{l}\text { Reduced browning of cold } \\
\text { exposure in mice }\end{array}$ & Jiang et al. (2017) \\
\hline & $\beta 2$ & Terbutaline (agonist) & Increased lipolysis in human & Enocksson et al. (1995) \\
\hline & \multirow[t]{2}{*}{$\beta 3$} & CL316,243 (agonists) & $\begin{array}{l}\text { Increased thermogenesis, } \\
\text { energy expenditure and BAT } \\
\text { hypertrophy in rats }\end{array}$ & Himms-Hagen et al. (1994) \\
\hline & & Mirabegron (agonists) & $\begin{array}{l}\text { BAT thermogenesis, WAT } \\
\text { lipolysis, and weight loss in } \\
\text { humans }\end{array}$ & Cypess, Weiner et al. (2015) \\
\hline \multirow[t]{3}{*}{$\alpha$ Adrenoceptors } & $\alpha 1$ & Midodrine (agonist) & $\begin{array}{l}\text { Increased PPAR } \delta \text {, p-AMPK, } \\
\text { and PGC-1 } \alpha \text { expression in } \\
\text { rats } \\
\text { Reduced lipid content in 3T3- } \\
\text { L1 adipocytes }\end{array}$ & Lee, Kim et al. (2020) \\
\hline & \multirow[t]{2}{*}{$\alpha 2$} & Yohimbine (antagonist) & $\begin{array}{l}\text { Reversed the noradrenaline } \\
\text { induced ERK phosphoryla- } \\
\text { tion in sASC of OA patients }\end{array}$ & Bagdadi et al. (2019) \\
\hline & & Clonidine (agonist) & $\begin{array}{l}\text { Decreased BAT thermogenesis } \\
\text { and emotional hyperther- } \\
\text { mia in rats }\end{array}$ & Antipov, Brizuela et al. (2020) \\
\hline \multirow[t]{10}{*}{ Adenosine receptors } & Non-selective & NECA (agonist) & $\begin{array}{l}\text { Reduction in body weight and } \\
\text { adiposity in mice }\end{array}$ & DeOliveira et al. (2017) \\
\hline & \multirow[t]{5}{*}{ A1 } & $\begin{array}{l}\text { N6-cyclopentyladenosine } \\
\text { (agonist) }\end{array}$ & $\begin{array}{l}\text { Reduction in basal lipolysis in } \\
\text { mice }\end{array}$ & DeOliveira et al. (2017) \\
\hline & & $\begin{array}{l}\text { Phenylisopropyladenosine } \\
\text { (agonist) }\end{array}$ & $\begin{array}{l}\text { Anti-lipolytic effect in human, } \\
\text { rat and dog adipocytes }\end{array}$ & $\begin{array}{l}\text { Hoffman et al. (1984), Strong } \\
\text { et al. (1993), Leiva, Guzmán- } \\
\text { Gutiérrez et al. (2017) }\end{array}$ \\
\hline & & 2-chloroadenosine (agonist) & Anti-lipolytic effect in rats & $\begin{array}{l}\text { Johansson et al. (2007), Leiva, } \\
\text { Guzmán-Gutiérrez et al. (2017) }\end{array}$ \\
\hline & & GR79236 (agonist) & $\begin{array}{l}\text { Reduction in circulating free } \\
\text { fatty acid in rats }\end{array}$ & $\begin{array}{l}\text { Strong et al. (1993), Tozzi and } \\
\text { Novak (2017a) }\end{array}$ \\
\hline & & & $\begin{array}{l}\text { Promote insulin sensitivity in } \\
\text { rats }\end{array}$ & $\begin{array}{l}\text { Meriño et al. (2017), Tozzi and } \\
\text { Novak (2017a) }\end{array}$ \\
\hline & \multirow[t]{4}{*}{$\mathrm{A} 2 \mathrm{~A}$} & CGS21680 (agonist) & $\begin{array}{l}\text { Increase in UCP1, } \\
\text { PPAR } \gamma \text {, PRDM16, and } \\
\text { CIDEA in mice }\end{array}$ & $\begin{array}{l}\text { Gnad et al. (2014), Ruan et al. } \\
\text { (2018), DeOliveira et al. } \\
\text { (2017) }\end{array}$ \\
\hline & & & $\begin{array}{l}\text { Enhanced lipolysis, FDG } \\
\text { uptake, glucose homeostasis } \\
\text { with increased insulin sensi- } \\
\text { tivity in mice }\end{array}$ & \\
\hline & & KW60020 (antagonist) & $\begin{array}{l}\text { Inhibit thermogenic gene } \\
\text { expression in brown adipo- } \\
\text { cyte }\end{array}$ & Ruan et al. (2018) \\
\hline & & SCH58261 (antagonist) & $\begin{array}{l}\text { Increase in fat mass in high- } \\
\text { sucurose diet fed rat }\end{array}$ & Sacramento et al. (2020) \\
\hline
\end{tabular}


Table 2 (continued)

\begin{tabular}{|c|c|c|c|c|}
\hline \multicolumn{2}{|l|}{ Subfamilies } & \multirow{2}{*}{$\begin{array}{l}\text { Pharmacological agents } \\
\text { BAY 60-6583 (agonist) }\end{array}$} & \multirow{2}{*}{$\begin{array}{l}\text { Effect } \\
\text { Reduced level of aging and } \\
\text { oxidative stress markers in } \\
\text { mice }\end{array}$} & \multirow{2}{*}{$\begin{array}{l}\text { References } \\
\text { Gnad et al. (2020) }\end{array}$} \\
\hline & $\mathrm{A} 2 \mathrm{~B}$ & & & \\
\hline & & PSB603 (antagonist) & $\begin{array}{l}\text { Reduction in oxygen consump- } \\
\text { tion in mice }\end{array}$ & Gnad et al. (2020) \\
\hline & & MRS1754 (antagonist) & Increase in weight gain in rats & Sacramento et al. (2020) \\
\hline \multirow[t]{3}{*}{ Lysophospholipid receptors } & LPA4-5 & $\begin{array}{l}\text { Octadecenyl phosphate (ago- } \\
\text { nist) }\end{array}$ & \multirow{2}{*}{$\begin{array}{l}\text { LPA4 selectively coupling } \\
\text { to G } \alpha 12 / 13 \text { proteins in } \\
\text { C3H10T1/2 derived adipo- } \\
\text { cytes }\end{array}$} & \multirow[t]{2}{*}{ Yanagida et al. (2018) } \\
\hline & LPA1-3 & Ki16425 (antagonist) & & \\
\hline & S1PR2 & JTE013 (antagonist) & $\begin{array}{l}\text { UCP1 expression in differenti- } \\
\text { ated primary adipogenic } \\
\text { progenitor cells }\end{array}$ & 'Gohlke, Zagoriy et al. (2019) \\
\hline
\end{tabular}

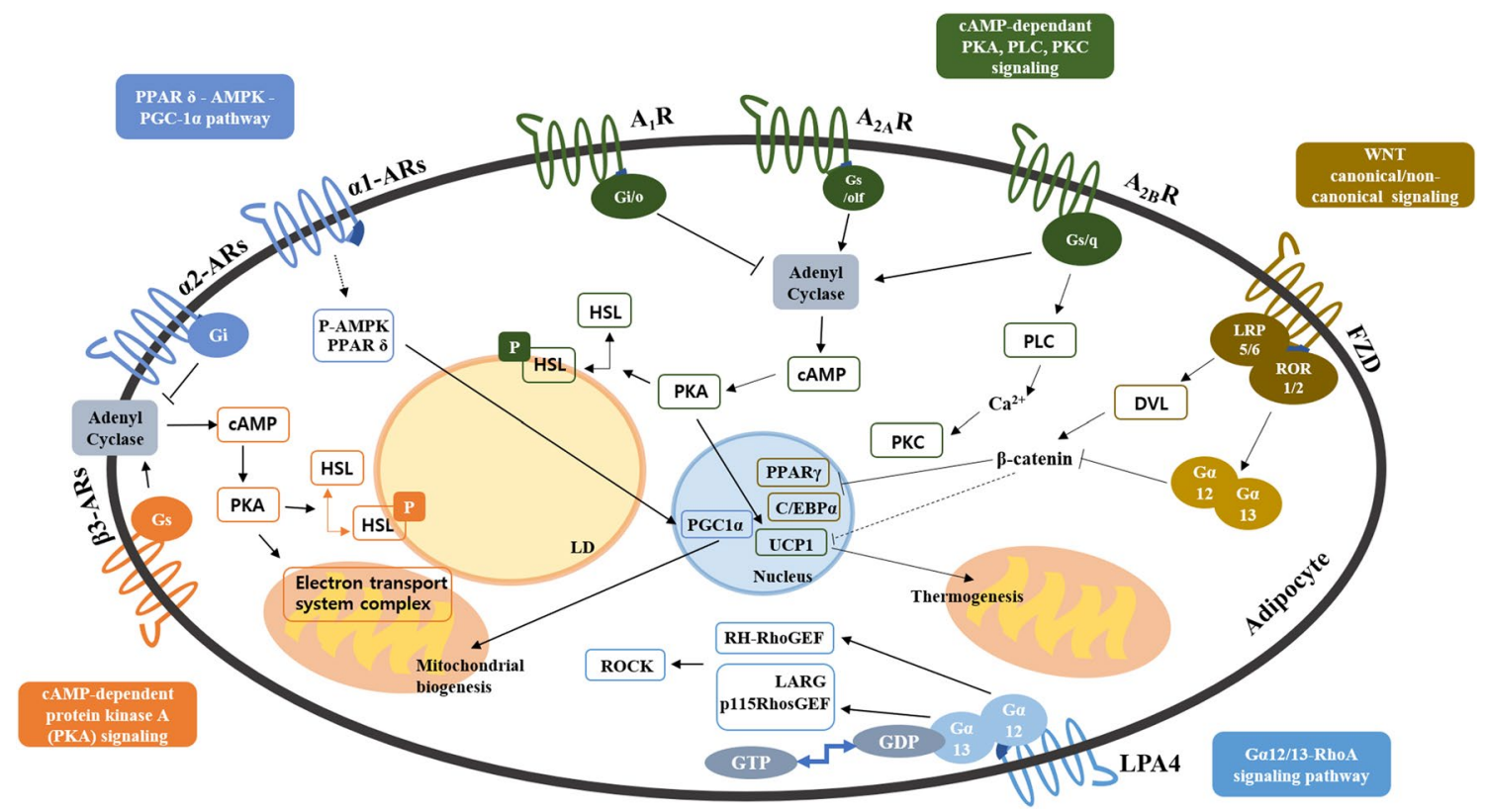

Fig. 2 Major signaling pathways of GPCR subfamilies. Figure 1 Metabolic signaling pathways of 5 subfamilies of GPCR: beta adrenoceptors, alpha adrenoceptors, adenosine receptors, frizzled receptors, and lysophospholipid receptors. In adipocytes, activated $\beta 3$-AR induces cAMP production, and cAMP binding leads to phosphorylation of PKA downstream substrates, such as hormone sensitive lipase (HSL) for lipolysis. The electron transport system complex modulates the oxidative phosphorylation of mitochondria. $A_{1} R$ inhibit adenylate cyclase activity and thus decrease cAMP levels, suppressing PKA signaling. $A_{2 A} R$ activates adenylate cyclase activity, leading to transcription of thermogenic genes like UCP1. Similarly, $A_{2 B} R$ increases cAMP levels by activation of adenylyl cyclase. $A_{2 B} R$ also stimulates phospholipase C; thus, both PKA and PKC signaling is promoted. FZD with LRP5/6 cause canonical WNT signaling, which increases the level of $\beta$-catenin. This causes inhibition of transcription of adipogenic genes, including PPAR $\gamma$ and C/EBP $\alpha$. With ROR1/2, FZD causes the reverse effects. WNT signaling is also involved in the expression of thermogenic genes in adipocytes, but the exact pathway is unknown. Upon ligand binding, $\mathrm{G} \alpha_{12 / 13}$ is activated by the transformation of GDP-bound form to GTP-bound form. G $\alpha_{12}$ regulates RH-RhoGEF, and $\mathrm{G} \alpha_{13}$ directly stimulates p115RhosGEF and leukemiaassociated Rho-GEF (LARG). Rho kinase (ROCK) is a downstream effector of the $\mathrm{G} \alpha_{12 / 13}$-RhoA signaling pathway

(Leiva et al. 2017). They couple to different G proteins, stimulating or inhibiting adenylyl cyclase. For instance, $A_{1}$ receptor $\left(A_{1} R\right)$ and $A_{3} R$ couple to $G_{i / o}$ proteins, causing inhibition of cAMP production by adenylyl cyclase and downregulation of PKA signaling, while $A_{2 A} R$ and $A_{2 B} R$ couple to $\mathrm{G}_{\mathrm{s} / \mathrm{olf}}$ proteins, promoting cAMP-mediated signaling pathways (Tozzi and Novak 2017b). These receptors are known to be associated with adipogenesis, lipolysis, adipose tissue inflammation, and insulin resistance (Csóka et al. 2014; Eisenstein et al. 2014), implying their potential 
as a pharmaceutical target for obesity and related metabolic syndromes (Pardo et al. 2017).

$\mathrm{A}_{1} \mathrm{Rs}$ are highly expressed in human white adipocytes, and when activated, they inhibit adenylate cyclase activity and cAMP production, leading to WAT lipolysis inhibition (Antonioli et al. 2015; Gnad et al. 2014). A reduction in the ex vivo basal lipolysis rate was observed in obese mice treated with $\mathrm{N}^{6}$-cyclopentyladenosine (CPA), an $\mathrm{A}_{1} \mathrm{R}$ agonist (DeOliveira et al. 2017). In addition, plasma levels of non-esterified fatty acids, glycerol, and triglycerides were reduced in CPA-treated wild-type mice (Johansson et al. 2008). Other $A_{1} R$ agonists, such as phenylisopropyladenosine, GR79236, and 2-chloroadenosine, exhibit antilipolytic effects following lipolysis induction in adipocytes from humans, rats, transgenic mice, and dogs (Hoffman et al. 1984; Strong et al. 1993; Johansson et al. 2007; Tozzi and Novak 2017a; Leiva et al. 2017). GR79236 also promotes insulin sensitivity in adipose tissue through a reduction in circulating FFA and triglyceride levels (Meriño et al. 2017). Simultaneously, $\mathrm{A}_{1} \mathrm{R}$ signaling promotes lipogenesis and modulates inflammation, shown by the absence of visceral adipose tissue (VAT) accumulation and proinflammatory cytokines (IL-1 $\beta$, IL-6, IL-12, and TNF- $\alpha$ ) in $\mathrm{A}_{1} \mathrm{R}$ knockout mice (Yang et al. 2015).

In contrast to $A_{1} R, A_{2 A}$ receptors $\left(A_{2 A} R\right)$ have a significantly higher expression in human brown adipocytes than in white adipocytes ( $\mathrm{Gnad}$ et al. 2014), and stimulate adenylate cyclase activity to promote lipolysis (Antonioli et al. 2015). It has also been reported that $\mathrm{A}_{2 \mathrm{~A}} \mathrm{R}$ signaling is necessary for the complete physiological functions of BAT (Gnad et al. 2014). Expression of thermogenic genes, including UCP1, PPAR $\gamma$, PRDM16, and CIDEA, is significantly increased by CGS21680, an $\mathrm{A}_{2 \mathrm{~A}} \mathrm{R}$ agonist, both in vitro and in vivo (Gnad et al. 2014; Ruan et al. 2018). Meanwhile, KW60020, an $\mathrm{A}_{2 \mathrm{~A}} \mathrm{R}$ antagonist, inhibits thermogenic gene expression (Ruan et al. 2018).

Enhancement in oxygen consumption, lipolysis, and fluorodeoxyglucose uptake was observed in mice injected with CGS21680 (Gnad et al. 2014). This improvement in glucose homeostasis correlating with increased insulin sensitivity was observed in obese mice treated for two weeks with CGS21680 (DeOliveira et al. 2017). Additionally, a high dose $(0.05 \mathrm{mg} / \mathrm{kg})$ of 5-N-ethylcarboxamidoadenosine, a non-selective agonist, resulted in a significant reduction in body weight and adiposity in obese mice. Consistently, $\mathrm{A}_{2 \mathrm{~A}} \mathrm{R}$ knockout mice gained more weight and showed an increase in visceral fat mass and adiposity after high-fat feeding (Ya et al. 2018). Chronic administration of $0.5 \mathrm{mg} /$ $\mathrm{kg} \mathrm{SCH58261,} \mathrm{an} \mathrm{A}_{2 \mathrm{~A}} \mathrm{R}$ antagonist, in rats fed with a highsucrose diet, led to an increase in fat (Sacramento et al. 2020). On the contrary, disruption of $A_{2 A} R$ resulted in the aggravation of a high-fat diet-induced adipose tissue inflammation (Ya et al. 2018).
$A_{2 B}$ receptor $\left(A_{2 B} R\right)$ is abundantly expressed in human BAT and is involved in its activity ( $\mathrm{Gnad}$ et al. 2020). Pharmacological stimulation of $\mathrm{A}_{2 \mathrm{~B}} \mathrm{R}$ causes a significant increase in oxygen consumption, while administration of PSB604, an $A_{2 B} R$ antagonist, or inhibition of $A_{2 B} R$, have the opposite effects (Gnad et al. 2020). In addition, a protective effect against age-induced oxidative stress was investigated in wild-type mice treated with BAY 60-6583, an $\mathrm{A}_{2 \mathrm{~B}} \mathrm{R}$ agonist (Gnad et al. 2020). This $A_{2 B} R$ stimulation increased the expression of thermogenic markers such as UCP1 in human WAT (Gnad et al. 2020). Conversely, the $A_{2 B} R$ antagonist MRS1754, promoted a significant weight gain in female and male rats (Sacramento et al. 2020).

Contradictory results from previous studies showed that adenosine inhibited the stimulatory effects of isoproterenol on oxygen uptake, lipolysis, and respiration in brown adipocytes of hamsters (Szillat and Bukowiecki 1983; Schimmel and McCarthy 1984). However, these discrepancies could be due to species-specific differences in the expression levels of adenosine receptor isotypes (Gnad et al. 2014).

As mentioned earlier, along with $A_{1} R$, the $A_{3}$ receptor $\left(\mathrm{A}_{3} \mathrm{R}\right)$ is also inhibitory since it couples with inhibitory Gi/ Go proteins to decrease cAMP levels (Pardo et al. 2017). Although both BAT and WAT express $\mathrm{A}_{3} \mathrm{R}$ ( Gnad et al. 2014), its activity in adipose tissue has not been thoroughly studied (DeOliveira et al. 2017). For instance, pharmacological inhibition of $A_{3} R$ with MRS1523 did not show significant lipolytic effects in murine brown adipocytes but it might indirectly contribute to metabolic activity, such as glucose homeostasis, through liver involvement (Gnad et al. 2014; Pardo et al. 2017).

\section{Frizzled receptors}

Frizzled (FZD) receptors, comprised of 10 subtypes (FZD1FZD10) (Zeng, Chen, and Fu 2018), are the main receptors for WNT ligands (Wang et al. 2016). They are considered unconventional GPCR proteins due to the lack of evidence of their interactions with G proteins (Nichols et al. 2013). However, recent studies have discovered the involvement of heterotrimeric G proteins in WNT/FZD signaling (Schulte and Wright 2018). Although FZD receptors are studied mainly through WNT signaling (Dijksterhuis, Petersen, and Schulte 2014; Petersen et al. 2017), understanding the GPCR nature of FZD receptors would enable their targeting to treat diseases (Schulte and Wright 2018). As WNT receptors, FZD receptors can act via three distinct pathways: canonical $/ \beta$-catenin, non-canonical/non- $\beta$-catenin, and the WNT and $\mathrm{Ca}^{2+}$ pathways (Nakamura et al. 2016). FZD genes, including FZD1, 2, 3, and 7, are highly expressed in VAT (Zuriaga et al. 2017).

In adipose tissue, it is known that FZD receptor-mediated WNT signaling affects adipogenesis and depending 
on the WNT type, it can promote or inhibit adipogenesis (van Tienen et al. 2009). For example, $\beta$-catenin-dependent WNT genes, including WNT10b and WNT3a, have been reported to inhibit adipogenesis by inhibiting PPAR $\gamma$ and $\mathrm{C} /$ EBP $\alpha$ expression (Nishizuka et al. 2008) while $\beta$-cateninindependent WNTs, including WNT5a and WNT5b, exert the opposite effect (Park et al. 2015). It has also been reported that WNT ligands can antagonize the function of one another as alternative WNT-YAP/TAZ-TEAD signaling, which couples to $\mathrm{G} \alpha_{12 / 13}$ proteins, activated by WNT5a, can suppress the effects of WNT/ $\beta$-catenin signaling that restrain adipogenesis (Park et al. 2015). Moreover, it has been shown that WNT3a promotes oxygen consumption and mitochondrial gene expression in ear mesenchymal stem cells adipocytes (Mori et al. 2012). FZD receptors can function differently depending on their ligands and co-receptors. For example, low-density lipoprotein receptor-related protein 5 (LRP5) or LRP6 activates the $\beta$-catenin signaling pathway, which inhibits adipocyte differentiation, while the FZD1 receptor and ROR $1 / 2$ co-receptor interacting with WNT5a/b can promote adipogenesis and inhibit the WNT-FZD/LRP pathway (Park et al. 2015; Loh et al. 2015). Metabolic stimulation, such as a high-fat diet, also affects WNT/ $\beta$-catenin signaling, causing activation of VAT adipocyte precursors "over-proliferation," which results in depot-specific hypertrophy and hyperplasia (Chen and Wang 2018). In addition, it has been reported that WNT signaling is associated with adipocyte browning, as pharmacological and genetic inhibition of WNT signaling resulted in an increased expression of thermogenic markers (UCP1, CIDEA) in primary mouse adipocytes (Lo et al. 2016). Recent studies have reported the possible WNT-FZD involvement in beige adipocytes differentiation (Chen and Wang 2018).

\section{Lysophospholipid receptors}

Lysophospholipids are bioactive lipid molecules that activate their specific GPCR as extracellular mediators (zu Heringdorf 2008). They are essential for cell growth and death and act as signaling molecules at inflammatory sites (Cas et al. 2020). Obesity impairing lysophospholipid metabolism generates inflammation and insulin resistance (Del Bas et al. 2016). Patients with type 1 diabetes and murine plasma lipid profiles were found to have decreased levels of long-chain lysophospholipids (Cas et al. 2020).

Lysophospholipid receptors, widely expressed in mammals, respond to lysophosphatidic acid (LPA) and sphingosine-1-phosphate (S1P) (Lemos et al. 2018). LPA and S1P receptors couple to different $G$ protein types (Table 2) and are emerging as important pharmacological targets with a research potential (Yanagida et al. 2018).
LPA is highly responsive to the control, traffic, and activation of immune cells and is therefore strongly associated with inflammatory diseases such as obesity and diabetes (Lemos et al. 2018). There are six types of LPA receptors, named LAP1-6 (Yung, Stoddard, and Chun 2014). An in vitro study showed that LPA1, LPA4, and LPA6 are expressed in C3H10T1/2 derived adipocytes (Yanagida et al. 2018). Studies using octadecenyl phosphate, a LPA4/5 agonist, and Ki16425, a LPA1-3 antagonist showed that LPA4 predominantly activates $\mathrm{G}_{12 / 13}$-RhoA pathway in C3H10T1/2 derived and primary cultured adipocytes (Yanagida et al. 2018). Rho-associated protein kinase (ROCK) is a downstream effector of the Go12/13-RhoA signaling pathway (Yang et al. 2020), and ROCK inhibitor treatment (Y-27632) and genetic deletion of ROCK enhance adipogenesis of 3T3L1 and mouse embryonic fibroblast (MEF) cells (Noguchi et al. 2007). Moreover, LPA treatment reduces differentiation of mouse primary brown preadipocytes, and overexpression of LPA-generating enzyme autotaxin (ATX) in mice significantly reduces expression levels of brown adipocyte markers and increases susceptibility to diet-induced obesity partly by limiting brown adipogenesis (Federico et al. 2012).

An in vivo study of LPA4 knockout mice showed upregulated mitochondrial and adipogenic gene expression in WAT (Yanagida et al. 2018). LPA4 limits the healthy expansion of WAT via $\mathrm{G} \alpha_{12 / 13}$ proteins in adipocytes; thus, a diet-induced obesity mouse model of LPA4 abrogation resulted in metabolically healthy obese phenotypes with ameliorated WAT inflammation and insulin resistance (Yanagida et al. 2018).

S1P receptors (S1PR) have five subtypes, namely S1PR1-5 (Hla and Brinkmann 2011). In adipose tissue, S1PR1, 4, and 5 are highly expressed in both BAT and WAT, while S1PR2 and S1PR3 are equally expressed in adipogenic progenitor cells (APCs) and its whole tissue (Gohlke et al. 2019). They couple to various G proteins; for instance, S1PR1 couples to $\mathrm{G} \alpha_{\mathrm{i}}, \mathrm{S} 1 \mathrm{PR} 2$ to $\mathrm{G} \alpha_{\mathrm{s}}, \mathrm{G} \alpha_{\mathrm{q}}$, or $\mathrm{G} \alpha_{12 / 13}$, S1PR3-5 to $\mathrm{G \alpha}_{\mathrm{i}}$, or $\mathrm{G} \alpha_{12 / 13}$ (Table 2).

$\mathrm{S} 1 \mathrm{P}$ concentrations are increased in adipose tissue of obese people (Ito et al. 2013). Similarly, S1P attenuated norepinephrine-induced expression of brown adipogenic genes in APCs obtained from mouse BAT (Gohlke et al. 2019). An in vitro study of primary mouse APCs was conducted with S1P receptor-specific antagonists: VPC23019 for S1PR1 and 3, JTE013 for S1PR2, and CYM50358 for S1PR4; it was found that S1PR2 was the most relevant subtype involved in adipocyte browning due to its particularly high expression in ASCs and increase in UCP1 expression induced by S1PR2 inhibition (Gohlke et al. 2019). In addition, S1PR2 mRNA expression levels were lower in mature adipocytes compared to APCs of mouse BAT and WAT (Gohlke et al. 2019). 


\section{Discussion}

Metabolic dysfunction of adipose tissue has been investigated as a key pathogenic mechanism leading to obesityrelated metabolic diseases (Rosen and Spiegelman 2014). Considering the critical roles that adipocytes have in metabolic homeostasis (Rosen and Spiegelman 2006), adipose tissue remains a promising target for new metabolic diseases therapeutics to restore energy balance and immune/endocrine function. With recent advances in our understanding of the molecular mechanisms regulating the development and activation of BAT, multiple endogenous or pharmacological activators have been tested to induce BAT activation/ expansion and WAT browning in humans (Bonet, Oliver, and Palou 2013; Kiefer 2017). Although there are currently no drug candidates demonstrating successful anti-obesity effects in clinical trials, many novel targets that regulate thermogenic pathways in adipose tissue have been identified in recent years (Loh, Kingwell, and Carey 2017). GPCRs are one of the most intensively investigated drug target families, and their broad disease indications might provide opportunities to develop novel therapeutics for metabolic diseases. In addition, there is a wealth of structural information and established functional assays for GPCR regulators. Therefore, understanding the roles of GPCRs in adipose tissue metabolism could help identify hidden disease-drug relationships and accelerate the drug discovery process for obesity and metabolic disorders.

Acknowledgements This research was supported by the National Research Foundation of Korea (NRF) grants (NRF2019R1C1C1002014, NRF-2018R1A5A2024425) funded by the Korean government (MSIT) (Y-HL)

\section{Compliance with ethical standards}

Conflict of interest The authors declare no conflicts of interest.

Open Access This article is licensed under a Creative Commons Attribution 4.0 International License, which permits use, sharing, adaptation, distribution and reproduction in any medium or format, as long as you give appropriate credit to the original author(s) and the source, provide a link to the Creative Commons licence, and indicate if changes were made. The images or other third party material in this article are included in the article's Creative Commons licence, unless indicated otherwise in a credit line to the material. If material is not included in the article's Creative Commons licence and your intended use is not permitted by statutory regulation or exceeds the permitted use, you will need to obtain permission directly from the copyright holder. To view a copy of this licence, visit http://creativecommons.org/licenses/by/4.0/.

\section{References}

Amer OY, Hebert-Chatelain E (2018) Mitochondrial cAMP-PKA signaling: what do we really know? Biochimica et Biophysica
Acta Bioenerg 1859:868-77. https://doi.org/10.1016/j.bbabi o.2018.04.005

Antipov A, Brizuela M, Blessing WW, Ootsuka Y (2020) Alpha2-adrenergic receptor agonists prevent emotional hyperthermia. Brain Res 1732:146678. https://doi.org/10.1016/j.brainres.2020.14667 8

Antonioli L, Blandizzi C, Csóka B, Pacher P, Haskó G (2015) Adenosine signalling in diabetes mellitus-pathophysiology and therapeutic considerations. Nat Rev Endocrinol 11:228-241. https:// doi.org/10.1038/nrendo.2015.10

Arch JRS (2002) $\beta 3$-Adrenoceptor agonists: potential, pitfalls and progress. Eur J Pharmacol 440:99-107. https://doi.org/10.1016/ S0014-2999(02)01421-8

Bengtsson T, Cannon B, Nedergaard J (2000) Differential adrenergic regulation of the gene expression of the $\beta$-adrenoceptor subtypes $\beta 1, \beta 2$ and $\beta 3$ in brown adipocytes. Biochem J. https://doi. org/10.1042/0264-6021:3470643

Bonet ML, Oliver P, Palou A (2013) Pharmacological and nutritional agents promoting browning of white adipose tissue. Biochimica et Biophysica Acta Mol Cell Biol Lipids 1831:969-985. https:// doi.org/10.1016/j.bbalip.2012.12.002

Bronnikov G, Houstěk J, Nedergaard J (1992) Beta-adrenergic, cAMPmediated stimulation of proliferation of brown fat cells in primary culture. Mediation via beta 1 but not via beta 3 adrenoceptors. J Biol Chem 267:2006-2013. https://doi.org/10.1016/S0021 $-9258(18) 46046-2$

Bronnikov G, Bengtsson T, Kramarova L, Golozoubova V, Cannon B, Nedergaard J (1999) $\beta 1$ to $\beta 3$ switch in control of cyclic adenosine monophosphate during brown adipocyte development explains distinct $\beta$-adrenoceptor subtype mediation of proliferation and differentiation. Endocrinology 140:4185-4197. https:// doi.org/10.1210/endo.140.9.6972

Cannon B, Nedergaard J (2004) Brown adipose tissue: function and physiological significance. Physiol Rev 84:277-359. https://doi. org/10.1152/physrev.00015.2003

Cas MD, Roda G, Li F, Secundo F (2020) Functional lipids in autoimmune inflammatory diseases. Int J Mol Sci 21:3074. https://doi. org/10.3390/ijms21093074

Chen Na, Wang J (2018) Wnt/ $\beta$-catenin signaling and obesity. Front Physiol 9:792-892. https://doi.org/10.3389/fphys.2018.00792

Chernogubova E, Hutchinson DS, Nedergaard J, Bengtsson T (2005a) $\alpha 1$-and $\beta 1$-adrenoceptor signaling fully compensates for $\beta 3$-adrenoceptor deficiency in brown adipocyte norepinephrinestimulated glucose uptake. Endocrinology 146:2271-2284. https ://doi.org/10.1210/en.2004-1104

Chernogubova E, Hutchinson DS, Nedergaard J, Bengtsson T (2005b) $\alpha 1-$ and $\beta 1$-adrenoceptor signaling fully compensates for $\beta 3$-adrenoceptor deficiency in brown adipocyte norepinephrinestimulated glucose uptake. Endocrinology 146:2271-2284. https ://doi.org/10.1210/en.2004-1104

Cho SY, Park PJ, Shin ES, Lee JH, Chang HK, Lee TR (2009) Proteomic analysis of mitochondrial proteins of basal and lipolytically (isoproterenol and TNF- $\alpha$ )-stimulated adipocytes. J Cell Biochem 106:257-266. https://doi.org/10.1002/jcb.21998

Collins S (2012) $\beta$-Adrenoceptor signaling networks in adipocytes for recruiting stored fat and energy expenditure. Front Endocrinol 2:102-202. https://doi.org/10.3389/fendo.2011.00102

Collins S, Daniel KW, Rohlfs EM, Ramkumar V, Taylor IL, Gettys TW (1994) Impaired expression and functional activity of the beta 3and beta 1-adrenergic receptors in adipose tissue of congenitally obese (C57BL/6J ob/ob) mice. Mol Endocrinol 8:518-527. https ://doi.org/10.1210/mend.8.4.7914350

Csóka B, Koscsó B, Törő G, Kókai E, Virág L, Németh ZH, Pacher P, Bai P, Haskó G (2014) A2B adenosine receptors prevent insulin resistance by inhibiting adipose tissue inflammation via 
maintaining alternative macrophage activation. Diabetes 63:850. https://doi.org/10.2337/db13-0573

Cypess AM, Lehman S, Williams G, Tal I, Rodman D, Goldfine AB, Kuo FC, Palmer EL, Tseng Y-H, Doria A, Kolodny GM, Ronald Kahn C (2009) Identification and Importance of Brown Adipose Tissue in Adult Humans. N Engl J Med 360:1509-1517. https:// doi.org/10.1056/NEJMoa0810780

Cypess AM, Weiner LS, Roberts-Toler C, Elía EF, Kessler SH, Kahn PA, English J, Chatman K, Trauger SA, Doria A, Kolodny GM (2015) Activation of human brown adipose tissue by a $\beta 3$-adrenergic receptor agonist. Cell Metab 21:33-38. https:// doi.org/10.1016/j.cmet.2014.12.009

de Souza Christopher J, Burkey Bryan F (2001) Beta3 -adrenoceptor agonists as anti-diabetic and anti-obesity drugs in humans. Curr Pharm Des 7:1433-49. https://doi.org/10.2174/1381612013 397339

Del Bas JM, Caimari A, Rodriguez-Naranjo MI, Childs CE, Paras Chavez C, West AL, Miles EA, Arola L, Calder PC (2016) Impairment of lysophospholipid metabolism in obesity: altered plasma profile and desensitization to the modulatory properties of n-3 polyunsaturated fatty acids in a randomized controlled trial. Am J Clin Nutr 104:266-279. https://doi.org/10.3945/ ajen.116.130872

DeOliveira CC, Gotardo EMF, Ribeiro ML, Gambero A (2017) Role of $\mathrm{A} 1$ and $\mathrm{A} 2 \mathrm{~A}$ adenosine receptor agonists in adipose tissue inflammation induced by obesity in mice. Eur J Pharmacol 799:154-59. https://doi.org/10.1016/j.ejphar.2017.02.017

Dijksterhuis JP, Petersen J, Schulte G (2014) WNT/Frizzled signalling: receptor-ligand selectivity with focus on FZD-G protein signalling and its physiological relevance: IUPHAR Review 3. Br J Pharmacol 171:1195-1209. https://doi.org/10.1111/bph.12364

Eisenstein A, Carroll SH, Johnston-Cox H, Farb M, Gokce N, Ravid K (2014) An adenosine receptor-Krüppel-like factor 4 protein axis inhibits adipogenesis. J Biol Chem 289:21071-21081. https:// doi.org/10.1074/jbc.M114.566406

El Bagdadi K, Karima FZ, Meurer A, Straub RH, Jenei-Lanzl Z (2019) Norepinephrine inhibits synovial adipose stem cell chondrogenesis via $\alpha 2$ a-adrenoceptor-mediated ERK1/2 activation. Int J Mol Sci 20:3127. https://doi.org/10.3390/ijms20133127

Enocksson S, Shimizu M, Lönnqvist F, Nordenström J, Arner P (1995) Demonstration of an in vivo functional beta 3 -adrenoceptor in man. J Clin Investig 95(5):2239-2245. https://doi.org/10.1172/ JCI117914

Ernande L, Stanford KI, Thoonen R, Zhang H, Clerte M, Hirshman MF, Goodyear LJ, Bloch KD, Buys ES, Scherrer-Crosbie M (2016) Relationship of brown adipose tissue perfusion and function: a study through $\beta 2$-adrenoreceptor stimulation. J Appl Physiol 120:825-832. https://doi.org/10.1152/japplphysiol.00634 2015

Evans BA, Merlin J, Bengtsson T, Hutchinson DS (2019) Adrenoceptors in white, brown, and brite adipocytes. Br J Pharmacol 176:2416-2432. https://doi.org/10.1111/bph.14631

Finlin BS, Memetimin H, Confides AL, Kasza I, Zhu B, Vekaria HJ, Harfmann B, Jones KA, Johnson ZR, Westgate PM, Alexander CM, Sullivan PG, Dupont-Versteegden EE, Kern PA (2018) Human adipose beiging in response to cold and mirabegron. JCI Insight 3:e121510. https://doi.org/10.1172/jci.insight.121510

Furukawa S, Fujita T, Shimabukuro M, Iwaki M, Yamada Y, Nakajima Y, Nakayama O, Makishima M, Matsuda M, Shimomura I (2017) Increased oxidative stress in obesity and its impact on metabolic syndrome. J Clin Investig 114:1752-1761. https://doi. org/10.1172/JCI21625

Gnad T, Scheibler S, von Kügelgen I, Scheele C, Kilić A, Glöde A, Hoffmann LS, Reverte-Salisa L, Horn P, Mutlu S, El-Tayeb A, Kranz M, Deuther-Conrad W, Brust P, Lidell ME, Betz MJ, Enerbäck S, Schrader J, Yegutkin GG, Müller CE, Pfeifer A (2014)
Adenosine activates brown adipose tissue and recruits beige adipocytes via A2A receptors. Nature 516:395-399. https://doi. org/10.1038/nature13816

Gnad T, Navarro G, Lahesmaa M, Reverte-Salisa L, Copperi F, Cordomi A, Naumann J, Hochhäuser A, Haufs-Brusberg S, Wenzel D, Suhr F, Jespersen NZ, Scheele C, Tsvilovskyy V, Brinkmann C, Rittweger J, Dani C, Kranz M, Deuther-Conrad W, Eltzschig HK, Niemi T, Taittonen M, Brust P, Nuutila P, Pardo L, Fleischmann BK, Blüher M, Franco R, Bloch W, Virtanen KA, Pfeifer A (2020) Adenosine/A2B receptor signaling ameliorates the effects of aging and counteracts obesity. Cell Metab 32:56-70. e7. https://doi.org/10.1016/j.cmet.2020.06.006

Gohlke S, Zagoriy V, Inostroza AC, Méret M, Mancini C, Japtok L, Schumacher F, Kuhlow D, Graja A, Stephanowitz H, Jähnert M, Krause E, Wernitz A, Petzke K-J, Schürmann A, Kleuser B, Schulz TJ (2019) Identification of functional lipid metabolism biomarkers of brown adipose tissue aging. Mol Metab 24:1-17. https://doi.org/10.1016/j.molmet.2019.03.011

Granneman JG, Lahners KN, Chaudhry A (1991) Molecular cloning and expression of the rat beta 3-adrenergic receptor. Mol Pharmacol 40:895

Green CJ, Frazer RS, Underhill S, Maycock P, Fairhurst JA, Campbell IT (1992) Metabolic effects of dobutamine in normal man. Clin Sci 82(1):77-83. https://doi.org/10.1042/cs0820077

Grundy SM (2004) Obesity, metabolic syndrome, and cardiovascular disease. J Clin Endocrinol Metab 89:2595-2600. https://doi. org/10.1210/jc.2004-0372

Gurdal H, Friedman E, Johnson MD (1995) Beta-adrenoceptor-G alpha $S$ coupling decreases with age in rat aorta. Mol Pharmacol 47:772

Hauser AS, Attwood MM, Rask-Andersen M, Schiöth HB, Gloriam DE (2017) Trends in GPCR drug discovery: new agents, targets and indications. Nat Rev Drug Discov 16:829-842. https://doi. org/10.1038/nrd.2017.178

Hayward LF, Mueller PJ, Hasser EM (2004) Adrenergic receptors. In: Martini Luciano (ed) Encyclopedia of endocrine diseases. New York, Elsevier

Himms-Hagen J, Cui J, Danforth E, Taatjes DJ, Lang SS, Waters BL, Claus TH (1994) Effect of CL-316,243, a thermogenic beta 3-agonist, on energy balance and brown and white adipose tissues in rats. Am J Physiol Regul Integr Comp Physiol 266(4):R1371R1382. https://doi.org/10.1152/ajpregu.1994.266.4.R1371

Hla T, Brinkmann V (2011) Sphingosine 1-phosphate (S1P). Neurology 76:S3. https://doi.org/10.1212/WNL.0b013e31820d5ec1

Hoffman BB, Chang H, Farahbakhsh Z, Reaven G (1984) Inhibition of lipolysis by adenosine is potentiated with age. J Clin Investig 74(5):1750-1755. https://doi.org/10.1172/JCI111593

Husted AS, Trauelsen M, Rudenko O, Hjorth SA, Schwartz TW (2017) GPCR-mediated signaling of metabolites. Cell Metab 25:777796. https://doi.org/10.1016/j.cmet.2017.03.008

Ito S, Iwaki S, Koike K, Yuda Y, Nagasaki A, Ohkawa R, Yatomi Y, Furumoto T, Tsutsui H, Sobel BE, Fujii S (2013) Increased plasma sphingosine-1-phosphate in obese individuals and its capacity to increase the expression of plasminogen activator inhibitor-1 in adipocytes. Coron Artery Dis 24:642-650. https ://doi.org/10.1097/mca.0000000000000033

Jiang Y, Berry DC, Graff JM (2017) Distinct cellular and molecular mechanisms for $\beta 3$ adrenergic receptorinduced beige adipocyte formation. eLife 6:30329. https://doi.org/10.7554/eLife.30329

Johansson Stina M, Salehi Albert, Sandström Marie E, Westerblad Håkan, Lundquist Ingmar, Carlsson Per-Ola, Fredholm Bertil B, Katz Abram (2007) A1 receptor deficiency causes increased insulin and glucagon secretion in mice. Biochem Pharmacol 74(11):1628-1635. https://doi.org/10.1016/j.bcp.2007.08.006

Johansson SM, Lindgren E, Yang J-N, Herling AW, Fredholm BB (2008) Adenosine A1 receptors regulate lipolysis and lipogenesis 
in mouse adipose tissue - interactions with insulin. Eur J Pharmacol 597:92-101. https://doi.org/10.1016/j.ejphar.2008.08.022

Kajimura S, Spiegelman BM, Seale P (2015) Brown and beige fat: physiological roles beyond heat generation. Cell Metab 22:546559. https://doi.org/10.1016/j.cmet.2015.09.007

Kershaw EE, Flier JS (2004) Adipose tissue as an endocrine organ. J Clin Endocrinol Metabol 89:2548-2556. https://doi.org/10.1210/ jc.2004-0395

Kiefer FW (2017) The significance of beige and brown fat in humans. Endocr Connect 6:R70-R79

Kim SH, Plutzky J (2016) Brown fat and browning for the treatment of obesity and related metabolic disorders. Diabetes Metab J 40:12-21. https://doi.org/10.4093/dmj.2016.40.1.12

Lafontan M, Berlan M (1981) Alpha-adrenergic receptors and the regulation of lipolysis in adipose tissue. Trends Pharmacol Sci 2:126-129. https://doi.org/10.1016/0165-6147(81)90286-8

Lee M-J, Yuanyuan Wu, Fried SK (2013) Adipose tissue heterogeneity: implication of depot differences in adipose tissue for obesity complications. Mol Aspects Med 34:1-11. https://doi. org/10.1016/j.mam.2012.10.001

Lee YH, Mottillo EP, Granneman JG (2014) Adipose tissue plasticity from WAT to BAT and in between. Biochimica et Biophysica Acta Mol Basis Dis 1842:358-369. https://doi.org/10.1016/j. bbadis.2013.05.011

Lee Y-H, Petkova AP, Konkar AA, Granneman JG (2015) Cellular origins of cold-induced brown adipocytes in adult mice. FASEB J 29:286-299. https://doi.org/10.1096/fj.14-263038

Lee Y-J, Kim HS, Seo HS, Na JO, Jang Y-N, Han Y-M, Kim H-M (2020) Stimulation of alpha(1)-adrenergic receptor ameliorates cellular functions of multiorgans beyond vasomotion through PPARס. PPAR Res 2020:3785137-3785237. https://doi. org/10.1155/2020/3785137

Leiva A, Guzmán-Gutiérrez E, Contreras-Duarte S, Fuenzalida B, Cantin C, Carvajal L, Salsoso R, Gutiérrez J, Pardo F, Sobrevia L (2017) Adenosine receptors: modulators of lipid availability that are controlled by lipid levels. Mol Aspects Med 55:26-44. https://doi.org/10.1016/j.mam.2017.01.007

Lemos JP, Smaniotto S, Messias CV, Moreira OC, Cotta-de-Almeida V, Dardenne M, Savino W, Mendes-da-Cruz DA (2018) Sphingosine-1-phosphate receptor 1 is involved in non-obese diabetic mouse thymocyte migration disorders. Int J Mol Sci 19:1446. https://doi.org/10.3390/ijms 19051446

Levin BE, Sullivan AC (1986) Beta-1 receptor is the predominant betaadrenoreceptor on rat brown adipose tissue. J Pharmacol Exp Ther 236:681-688

Lo KA, Ng PY, Kabiri Z, Virshup D, Sun L (2016) Wnt inhibition enhances browning of mouse primary white adipocytes. Adipocyte 5:224-231. https://doi.org/10.1080/21623945.2016.1148834

Loh NY, Neville MJ, Marinou K, Hardcastle SA, Fielding BA, Duncan EL, McCarthy MI, Tobias JH, Gregson CL, Karpe F, Christodoulides C (2015) LRP5 regulates human body fat distribution by modulating adipose progenitor biology in a dose- and depot-specific fashion. Cell Metab 21:262-273. https://doi.org/10.1016/j. cmet.2015.01.009

Loh RKC, Kingwell BA, Carey AL (2017) Human brown adipose tissue as a target for obesity management; beyond cold-induced thermogenesis. Obes Rev 18:1227-1242. https://doi.org/10.1111/ obr.12584

Lorenzo F, Ren H, Mueller PA, Wu T, Liu S, Popovic J, Blalock EM, Sunkara M, Ovaa H, Albers HM, Mills GB, Morris AJ, Smyth SS (2012) Autotaxin and its product lysophosphatidic acid suppress brown adipose differentiation and promote diet-induced obesity in mice. Mol Endocrinol 26:786-97. https://doi.org/10.1210/ me.2011-1229

Malik M, van Gelderen EM, Lee JH, Kowalski DL, Yen M, Goldwater R, Mujais SK, Schaddelee MP, de Koning P, Kaibara A, Moy SS,
Keirns JJ (2012) Proarrhythmic safety of repeat doses of mirabegron in healthy subjects: a randomized, double-blind, placebo-, and active-controlled thorough QT study. Clin Pharmacol Ther 92:696-706. https://doi.org/10.1038/clpt.2012.181

Marinissen MJ, Silvio Gutkind J (2001) G-protein-coupled receptors and signaling networks: emerging paradigms. Trends Pharmacol Sci 22:368-376. https://doi.org/10.1016/S0165-6147(00)01678-3

Meriño M, Briones L, Palma V, Herlitz K, Escudero C (2017) Role of adenosine receptors in the adipocyte-macrophage interaction during obesity. Endocrinología Diabetes y Nutrición (English ed) 64:317-327. https://doi.org/10.1016/j.endien.2017.08.001

Mori H, Prestwich TC, Reid MA, Longo KA, Gerin I, Cawthorn WP, Susulic VS, Krishnan V, Greenfield A, Macdougald OA (2012) Secreted frizzled-related protein 5 suppresses adipocyte mitochondrial metabolism through WNT inhibition. J Clin Investig 122:2405-2416. https://doi.org/10.1172/JCI63604

Nakamura K, Sano S, Fuster JJ, Kikuchi R, Shimizu I, Ohshima K, Katanasaka Y, Ouchi N, Walsh K (2016) Secreted Frizzledrelated protein 5 diminishes cardiac inflammation and protects the heart from ischemia/reperfusion injury. J Biol Chem 291:2566-2575. https://doi.org/10.1074/jbc.M115.693937

Nichols AS, Floyd DH, Bruinsma SP, Narzinski K, Baranski TJ (2013) Frizzled receptors signal through G proteins. Cell Signal 25:1468-1475. https://doi.org/10.1016/j.cellsig.2013.03.009

Nishizuka M, Koyanagi A, Osada S, Imagawa M (2008) Wnt4 and Wnt5a promote adipocyte differentiation. FEBS Lett 582:32013205. https://doi.org/10.1016/j.febslet.2008.08.011

Noguchi M, Hosoda K, Fujikura J, Fujimoto M, Iwakura H, Tomita T, Ishii T, Arai N, Hirata M, Ebihara K, Masuzaki H, Itoh H, Narumiya S, Nakao K (2007) Genetic and pharmacological inhibition of rho-associated kinase II enhances adipogenesis. J Biol Chem 282:29574-29583. https://doi.org/10.1074/jbc.M705972200

Pardo F, Villalobos-Labra R, Chiarello DI, Salsoso R, Toledo F, Gutierrez J, Leiva A, Sobrevia L (2017) Molecular implications of adenosine in obesity. Mol Aspects Med 55:90-101. https://doi. org/10.1016/j.mam.2017.01.003

Park HW, Kim YC, Bo Yu, Moroishi T, Mo J-S, Plouffe SW, Meng Z, Lin KC, Fa-Xing Yu, Alexander CM, Wang C-Y, Guan K-L (2015) Alternative Wnt signaling activates YAP/TAZ. Cell 162:780-794. https://doi.org/10.1016/j.cell.2015.07.013

Peng X-R, Gennemark P, O’Mahony G, Bartesaghi S (2015) Unlock the thermogenic potential of adipose tissue: pharmacological modulation and implications for treatment of diabetes and obesity. Front Endocrinol. https://doi.org/10.3389/fendo.2015.00174

Petersen J, Wright SC, Rodríguez D, Matricon P, Lahav N, Vromen A, Friedler A, Strömqvist J, Wennmalm S, Carlsson J, Schulte G (2017) Agonist-induced dimer dissociation as a macromolecular step in G protein-coupled receptor signaling. Nat Commun 8:226. https://doi.org/10.1038/s41467-017-00253-9

Pradhan RN, Zachara M, Deplancke B (2017) A systems perspective on brown adipogenesis and metabolic activation. Obes Rev 18:65-81. https://doi.org/10.1111/obr.12512

Quiñones M, Fernø J, Diéguez C, Nogueiras R, Al-Massadi O (2019) Exciting advances in GPCR-based drugs discovery for treating metabolic disease and future perspectives. Expert Opin Drug Discov 14:421-431. https://doi.org/10.1080/17460 441.2019.1583642

Ramseyer VD, Granneman JG (2016) Adrenergic regulation of cellular plasticity in brown, beige/brite and white adipose tissues. Adipocyte 5:119-129. https://doi.org/10.1080/21623945.2016.1145846

Riis-Vestergaard MJ, Richelsen B, Bruun JM, Li W, Hansen JB, Pedersen SB (2020) Beta-1 and not beta- 3 adrenergic receptors may be the primary regulator of human brown adipocyte metabolism. J Clin Endocrinol Metab. https://doi.org/10.1210/clinem/dgz298 
Rosen ED, Spiegelman BM (2006) Adipocytes as regulators of energy balance and glucose homeostasis. Nature 444:847-853. https:// doi.org/10.1038/nature05483

Rosen ED, Spiegelman BM (2014) What we talk about when we talk about fat. Cell 156:20-44. https://doi.org/10.1016/j. cell.2013.12.012

Rosen H, Gonzalez-Cabrera PJ, Germana Sanna M, Brown S (2009) Sphingosine 1-phosphate receptor signaling. Annu Rev Biochem 78:743-768. https://doi.org/10.1146/annurev.biochem.78.07240 7.103733

Rothwell NJ, Stock MJ, Sudera DK (1985) Beta-adrenoreceptors in rat brown adipose tissue: proportions of beta 1-and beta 2-subtypes. Am J Physiol Endocrinol Metab 248:E397-E402. https:// doi.org/10.1152/ajpendo.1985.248.4.E397

Ruan C-C, Kong L-R, Xiao-Hui Chen Yu, Ma X-X, Zhang Z-B, Gao P-J (2018) A2A receptor activation attenuates hypertensive cardiac remodeling via promoting brown adipose tissue-derived FGF21. Cell Metab 28:476-89.e5. https://doi.org/10.1016/j. cmet.2018.06.013

Sacramento JF, Martins FO, Rodrigues T, Matafome P, Ribeiro MJ, Olea E, Conde SV (2020) A2 adenosine receptors mediate whole-body insulin sensitivity in a prediabetes animal model: primary effects on skeletal muscle. Front Endocrinol. https://doi. org/10.3389/fendo.2020.00262

Samuel VT, Shulman GI (2012) Mechanisms for insulin resistance: common threads and missing links. Cell 148:852-871. https:// doi.org/10.1016/j.cell.2012.02.017

Schimmel RJ, McCarthy L (1984) Role of adenosine as an endogenous regulator of respiration in hamster brown adipocytes. Am J Physiol 246:C301-C307. https://doi.org/10.1152/ajpce 11.1984.246.3.C301

Schulte G, Wright SC (2018) Frizzleds as GPCRs - more conventional than we thought! Trends Pharmacol Sci 39:828-842. https://doi. org/10.1016/j.tips.2018.07.001

Shin JH, Lee SH, Kim YN, Kim IY, Kim YJ, Kyeong DS, Lim HJ, Cho SY, Choi J, Wi YJ, Choi J-H, Yoon YS, Bae YS, Seong JK (2016) AHNAK deficiency promotes browning and lipolysis in mice via increased responsiveness to $\beta$-adrenergic signalling. Sci Rep 6:23426-23526. https://doi.org/10.1038/srep23426

Sloop KW, Emmerson PJ, Statnick MA, Willard FS (2018) The current state of GPCR-based drug discovery to treat metabolic disease. Br J Pharmacol 175:4060-4071. https://doi.org/10.1111/ bph. 14157

Strong P, Anderson R, Coates J, Elus F, Evans B, Gurden MF, Johnstone J, Kennedy I, Martin DP (1993) Suppression of non-esterified fatty acids and triacylglycerol in experimental animals by the adenosine analogue GR79236. Clin Sci 84(6):663-669. https ://doi.org/10.1042/cs0840663

Sun K, Tordjman J, Clément K, Scherer PE (2013) Fibrosis and adipose tissue dysfunction. Cell Metab 18:470-477. https://doi. org/10.1016/j.cmet.2013.06.016

Syrovatkina V, Alegre KO, Dey R, Huang X-Y (2016) Regulation, signaling, and physiological functions of G-proteins. J Mol Biol 428:3850-3868. https://doi.org/10.1016/j.jmb.2016.08.002

Szillat D, Bukowiecki LJ (1983) Control of brown adipose tissue lipolysis and respiration by adenosine. Am J Physiol 245:E555-E559. https://doi.org/10.1152/ajpendo.1983.245.6.E555

Tozzi M, Novak I (2017a) Purinergic Receptors in adipose tissue as potential targets in metabolic disorders. Front Pharmacol 8:878978. https://doi.org/10.3389/fphar.2017.00878

Tozzi M, Novak I (2017b) Purinergic receptors in adipose tissue as potential targets in metabolic disorders. Front Pharmacol. https ://doi.org/10.3389/fphar.2017.00878
Trayhurn P, Beattie JH (2001) Physiological role of adipose tissue: white adipose tissue as an endocrine and secretory organ. Proc Nutr Soc 60:329-339. https://doi.org/10.1079/PNS200194

Ueta CB, Fernandes GW, Capelo LP, Fonseca TL, Maculan FD, Gouveia CHA, Brum PC, Christoffolete MA, Aoki MS, Lancellotti CL (2012) $\beta 1$ Adrenergic receptor is key to cold-and diet-induced thermogenesis in mice. J Endocr 214:359. https:// doi.org/10.1530/JOE-12-0155

Valet P, Grujic D, Wade J, Ito M, Zingaretti MC, Soloveva V, Ross SR, Graves RA, Cinti S, Lafontan M, Lowell BB (2000) Expression of human alpha 2-adrenergic receptors in adipose tissue of beta 3-adrenergic receptor-deficient mice promotes diet-induced obesity. J Biol Chem 275:34797-34802. https://doi.org/10.1074/ jbc.M005210200

van Tienen FHJ, Laeremans H, van der Kallen CJH, Smeets HJM (2009) Wnt5b stimulates adipogenesis by activating PPAR $\gamma$, and inhibiting the $\beta$-catenin dependent Wnt signaling pathway together with Wnt5a. Biochem Biophys Res Commun 387:207211. https://doi.org/10.1016/j.bbrc.2009.07.004

Verboven K, Wouters K, Gaens K, Hansen D, Bijnen M, Wetzels S, Stehouwer CD, Goossens GH, Schalkwijk CG, Blaak EE, Jocken JW (2018) Abdominal subcutaneous and visceral adipocyte size, lipolysis and inflammation relate to insulin resistance in male obese humans. Sci Rep 8:4677. https://doi.org/10.1038/s4159 8-018-22962-x

Virtanen KA, Lidell ME, Orava J, Heglind M, Westergren R, Niemi T, Taittonen M, Laine J, Savisto N-J, Enerbäck S, Nuutila P (2009) Functional brown adipose tissue in healthy adults. N Engl J Med 360:1518-1525. https://doi.org/10.1056/NEJMoa0808949

Wang Y, Chang H, Rattner A, Nathans J (2016) Frizzled receptors in development and disease. Curr Top Dev Biol 117:113-139. https ://doi.org/10.1016/bs.ctdb.2015.11.028

Weis WI, Kobilka BK (2018) The molecular basis of G protein-coupled receptor activation. Annu Rev Biochem 87:897-919. https://doi. org/10.1146/annurev-biochem-060614-033910

Ya P, Honggui Li, Yuli C, Jing Z, Xianjun L, Linqiang Ma, Kelly McDaniel, Tianshu Z, Yanming C, Xiaoxian Q, Yuqing H, Shannon G, Fanyin M, Gianfranco A, Lulu C, Chaodong Wu (2018) Regulation of adipose tissue inflammation by adenosine $2 \mathrm{~A}$ receptor in obese mice. J Endocrinol 239:365-376. https://doi. org/10.1530/JOE-18-0169

Yanagida K, Igarashi H, Yasuda D, Kobayashi D, Ohto-Nakanishi T, Akahoshi N, Sekiba A, Toyoda T, Ishijima T, Nakai Y, Shojima N, Kubota N, Abe K, Kadowaki T, Ishii S, Shimizu T (2018) The Go12/13-coupled receptor LPA4 limits proper adipose tissue expansion and remodeling in diet-induced obesity. JCI insight. https://doi.org/10.1172/jci.insight.97293

Yang T, Gao X, Sandberg M, Zollbrecht C, Zhang X-M, Hezel M, Liu M, Peleli M, Lai E-Y, Harris RA, Erik A, Persson G, Fredholm BB, Jansson L, Carlström M (2015) Abrogation of adenosine A1 receptor signalling improves metabolic regulation in mice by modulating oxidative stress and inflammatory responses. Diabetologia 58:1610-1620. https://doi.org/10.1007/s0012 5-015-3570-3

Yang YM, Kuen D-S, Chung Y, Kurose H, Kim SG (2020) Go12/13 signaling in metabolic diseases. Exp Mol Med 52:896-910. https ://doi.org/10.1038/s12276-020-0454-5

Yung YC, Stoddard NC, Chun J (2014) LPA receptor signaling: pharmacology, physiology, and pathophysiology. J Lipid Res 55:1192-1214. https://doi.org/10.1194/jlr.r046458

Zeng C-M, Chen Z, Li Fu (2018) Frizzled receptors as potential therapeutic targets in human cancers. Int J Mol Sci 19:1543. https:// doi.org/10.3390/ijms 19051543 
zu Herindorf DM (2008) Lysophospholipds. In: Offermanns Stefan, Rosenthal Walter (eds) Encyclopedia of endocrine diseases. Berlin, Heidelberg, Springer

Zuriaga MA, Fuster JJ, Farb MG, MacLauchlan S, Bretón-Romero R, Karki S, Hess DT, Apovian CM, Hamburg NM, Gokce N, Walsh K (2017) Activation of non-canonical WNT signaling in human visceral adipose tissue contributes to local and systemic inflammation. Scientific Reports 7:17326-17426. https://doi. org/10.1038/s41598-017-17509-5
Publisher's Note Springer Nature remains neutral with regard to jurisdictional claims in published maps and institutional affiliations. 